\title{
Streptococcus pneumoniae isolates in healthy children attending day-care centers in 12 states in Mexico
}

\author{
Luz Elena Espinosa-de los Monteros, D en C,(1) Verónica Jiménez-Rojas, M en C, ${ }^{(2)}$ Felipe Aguilar-Ituarte, MC, ${ }^{(2)}$ \\ Miguel Cashat-Cruz, M en C, (2) Alfonso Reyes-López, M en C,(2) Romeo Rodríguez-Suárez, MC,(3) \\ Pablo Kuri-Morales, M en C, ${ }^{(4)}$ Roberto Tapia-Conyer, M en C, ${ }^{(5)}$ Demóstenes Gómez-Barreto, MC. ${ }^{(1)}$
}

Espinosa-de los Monteros LE, Jiménez-Rojas V,Aguilar-Ituarte F,
Cashat-Cruz M, Reyes-López A, Rodríguez-Suárez R et al.
Streptococcus pneumoniae isolates in healthy
children attending day-care centers in 12 states in Mexico.
Salud Publica Mex 2007:49:249-255.

\begin{abstract}
Objective. The aim of this study was to determine the prevalence of asymptomatic nasopharyngeal carriage of Streptococcus pneumoniae, which is a major factor in the transmission of this bacterium. Material and Methods. Nasopharyngeal cultures were performed on children attending 32 day-care centers in 12 states in Mexico. Results. Streptococcus pneumoniae was isolated from the nasopharynx of 829 out of $2777(29.9 \%)$ subjects aged two months to six years. All children lived in urban areas and $80 \%$ spent more than six hours daily in a day-care center. Streptococcus pneumoniae serotypes most frequently identified were: I9F (23\%), 6B (I5.6\%), 23F (II.2\%) and 6A (I4.9\%). Thirtysix percent of the isolates were susceptible to penicillin. Conclusions. Serotype distribution suggests the possible benefits that could be obtained from the heptavalent pneumococcal conjugate vaccine.
\end{abstract}

Key words: S. pneumoniae; nasopharyngeal carriage; day-care center; Mexico
Espinosa-de los Monteros LE, Jiménez-Rojas V, Aguilar-ltuarte F, Cashat-Cruz M, Reyes-López A, Rodríguez-Suárez R et al. Aislamientos de $S$. pneumoniae en niños sanos de estancias infantiles en 12 estados de México.

Salud Publica Mex 2007;49:249-255.

\section{Resumen}

Objetivo. La intención de este estudio fue determinar la prevalencia de portadores nasofaríngeos asintomáticos de Streptococcus pneumoniae, el cual es el principal factor en la transmisión de esta bacteria. Material y métodos. Los cultivos nasofaríngeos fueron realizados en niños que asisten a 32 estancias infantiles en 12 estados de México. Resultados. Streptococcus pneumoniae fue aislado de la nasofaringe de 829 (29.9\%) niños de los 2777 incluidos en el estudio con un rango de edad de 2 meses a 6 años. Todos los niños vivían en áreas urbanas y $80 \%$ permanecían más de seis horas diarias en la estancia infantil. Los serotipos de Streptococcus pneumoniae más frecuentemente identificados fueron: $19 \mathrm{~F}$ (23\%), 6B (I5.6\%), 23F (II.2\%) y $6 \mathrm{~A}(\mathrm{I} 4.9 \%)$. Treinta y seis por ciento de los aislamientos fueron susceptibles a penicilina. Conclusiones. La distribución de serotipos nos da una idea de los posibles beneficios que podrían obtenerse de la vacuna neumocóccica conjugada heptavalente.

Palabras clave: S.pneumoniae; portador nasofaríngeo; estancia infantil; México

(I) Hospital General Dr. Manuel Gea González. México.

(2) Hospital Infantil de México Federico Gómez.

(3) Centro Nacional para la Salud de la Infancia y la Adolescencia, Secretaría de Salud. México.

(4) Dirección General de Epidemiología, Secretaría de Salud. México.

(5) Subsecretaría de Prevención y Promoción de la Salud, Secretaría de Salud. México.

Received on: August 25, 2006 • Accepted on: March 21, 2007

Address reprint requests to: Luz Elena Espinosa de los Monteros Pérez. Hospital General Dr. Manuel Gea González, Departamento de investigación en microbiología. Calzada de Tlalpan 4800. Colonia Sección XVI. Delegación Tlalpan, I 4080 México DF.

E-mail: espinosaluzelena@hotmail.com 
$\mathrm{T}$ he normal nasopharynx microflora in human beings constitutes a reservoir of respiratory tract pathogens that are associated with respiratory tract and invasive infections. ${ }^{1}$ Generally, the bacteria that colonize the nasopharynx in healthy individuals circulate in the community. ${ }^{2}$ One of the most important potential pathogens found in the microflora of the nasopharynx is Streptococcus pneumoniae. Nasopharyngeal colonization has been associated with invasive infection. ${ }^{2}$ Children under five years of age who attend day-care centers are at a greater risk of being asymptomatic nasopharyngeal carriers and consequently have a greater risk of developing pathological processes related to S. pneumoniae. Sixty-five percent of pneumococcal infections occur in children under two years of age. This rises to $85 \%$ in children under four years of age. . $^{3,4}$

In recent years, $S$. pneumoniae has demonstrated increasing resistance to commonly used antibiotics, especially penicillin. These antibiotic-resistant strains are more frequently found in children carriers than in adult carriers. Antibiotic-resistant Streptococcus pneumoniae strains are usually associated with a limited number of serotypes and these serotypes are frequent causes of invasive pediatric infections. . $^{5-7}$

Day-care attendance has also been associated with S. pneumoniae carriage, antimicrobial resistance ${ }^{8-10}$ and an increased risk of invasive pneumococcal disease. ${ }^{11}$

In Mexico, nationwide information is lacking about the prevalence of pneumococcal colonization, colonizing serotypes and penicillin susceptibility in healthy children under five years old.

Since the pathophysiology of localized and invasive infection usually is preceded by nasopharyngeal colonization, an understanding of nasopharyngeal carriage prevalence, serotype distribution and antibiotic susceptibility is of importance, especially in light of the availability of a conjugate pneumococcal vaccine that has demonstrated a decrease in the carriage rates of vaccine serotypes in immunized children. ${ }^{12,13}$

\section{Material and Methods}

Participants: A cross-sectional study of healthy children aged two months to six years attending day-care centers per city in 12 states in Mexico (15 different cities, Toluca, Mexico State; Mexico City, Federal District; Monterrey, Nuevo Leon; Xalapa, Veracruz; Zamora, Michoacan; Tampico, Tamaulipas; City of Madero, Tamaulipas; Oaxaca, Oaxaca; Ensenada, Baja California; Tijuana, Baja California; Tecate, Baja California; Leon, Guanajuato; Jalisco, Guadalajara; Pachuca, Hidalgo; San Luis Potosi,
San Luis Potosi) was conducted between September and December 2002. Informed consent was obtained from all study participants. The study was approved by the local Research and Ethics Committee.

Sample selection: a non-probabilistic sampling was carried out in which private and governmental day-care centers were included (IMSS; ISSTE; PEMEX). The calculation of the sample was conducted with the statistical package EPI Info version 6.04, using 30\% as a threshold for prevalence of the disease, and a level of significance of $95 \%$, which resulted in 81 children for each infantile stay, for which it was necessary to study at least two day-care centers.

Children with primary or acquired immunodeficiency diseases, hematological and/or oncological disease, bronchopulmonary dysplasia, acute respiratory tract infections (ARI), use of steroids or immunosuppressive drugs and craniofacial malformations were excluded from this study.

Specimen collection: specimens were collected by inserting a calgiswab ${ }^{\circledR}$ (Pur-Wraps) into the nasopharynx. Swabs were placed directly into the Stuart transport medium and were sent to Streptocci's Laboratory at the Hospital Infantil de Mexico.

Laboratory Methods: Swabs were plated onto 5\% defibrinated sheep blood agar (Dickinson Microbiology Systems, Maryland, USA) and incubated at $37^{\circ} \mathrm{C}$ for 24 hours under a $10 \% \mathrm{CO}_{2}$ atmosphere. Three colonies that were morphologically typical of S.pneumoniae were selected for identification on the basis of colonial and microscopic morphology, susceptibility to optochin and solubility in bile. Serotyping was performed by the Quellung reaction using serotype-specific pneumococcal antisera from Statens Serum Institute, (Copenhagen, Denmark). All isolates were sero- and factor typed according to the nomenclature of the Danish system. If pneumococcal colonies of multiple morphologies were present, each morphological type was serotyped. ${ }^{14}$ Susceptibility to penicillin was determined by microdilution for all isolates of S.pneumoniae, following the norms established by The Clinical and Laboratory Standards Institute, formerly known as The National Committee for Clinical Laboratory Standards (NCCLS). ${ }^{15}$

BacterialQC Strains: S.pneumoniae 23F ATCC700669, S.pneumoniae 6B ATCC700670, S.pneumoniae 9V ATCC700671, S.pneumoniae 14 ATCC700902 and S.pneumoniae ATCC49619.

Statistical Analysis: Frequencies, measures of central tendency and dispersion, percentages as well as prevalence were determined. $P$-value was obtained by z-test for proportions. 


\section{Results}

From the 15 participant cities in 12 states in the Mexican Republic, 32 day-care centers were included, with a total of 2777 children (figure 1). All the children lived in urban areas, had entered the day-care center at least one month before the beginning of the study and had an average stay of six hours daily at the day-care center. Among the children included in the study, none had received the 7-valent pneumococcal conjugate vaccine.

Microbiology: Streptococcus pneumoniae was isolated in 829 of the 2777 (29.9\%) specimens. The median age of children who carried Streptococcus penumoniae was 3.12 years compared to those who were not carriers (3.34 years) $(p$-value $=0.006)$. The $<6$ months age group had a higher risk of being a carrier of S.pneumoniae compared to the other age groups $(p=0.003)$ (table I).

Serotype distribution:The distribution of serotypes is shown in table II. The most frequent serotypes were: 19F $(23 \%), 6 \mathrm{~B}(15,6 \%), 23 \mathrm{~F}(11.2 \%), 6 \mathrm{~A}(14.3 \%), 19 \mathrm{~A}$ $(6 \%), 11 \mathrm{~A}(4.1 \%)$ and $35 \mathrm{~B}(3.86 \%)$. Fifty-six percent of serotypes isolated were represented in the heptavalent pneumococcal conjugate vaccine, $56.7 \%$ and $77.9 \%$ were represented in the experimental $11 \mathrm{~V}^{16}[1,3,4,5,6 \mathrm{~B}, 7 \mathrm{~F}, 9 \mathrm{~V}$, $14,18 \mathrm{C}, 19 \mathrm{~F}, 23 \mathrm{~F}]$ and $13 \mathrm{~V}^{17}[1,3,4,5,6 \mathrm{~A}, 6 \mathrm{~B}, 7 \mathrm{~F}, 9 \mathrm{~V}, 14,18 \mathrm{C}, 1$ 9A,19F,23F] conjugate pneumococcal vaccines.

Antibiotic Resistance: Results of penicillin susceptibility testing are shown in table II. Thirty-six percent of
Table I

DISTRIBUTION BY AGE-GROUPS OF SEROTYPES OF STREPTOCOCCUS PNEUMONIAE ISOLATED FROM CARRIER CHILDREN ATTENDING DAY-CARE Centers IN MeXico

\begin{tabular}{lcrcc} 
Group-Age & Carrier & $\%$ & $P$ value $\left(\mathrm{Chi}^{2}\right)$ & OR (IC 95\%) \\
$<6$ month & 46 & 5.5 & 0.03 & $\mathrm{I} .5(\mathrm{I} .03-2.2)$ \\
\hline 6 months- Iyear & 40 & 4.8 & 0.07 & $0.7(0.5-1.03)$ \\
\hline I-2 years & 138 & 16.6 & 0.2 & $\mathrm{I} .16(0.9-1.4)$ \\
\hline $2-5$ years & 487 & 58.7 & 0.46 & $\mathrm{I} .06(0.9-1.2)$ \\
\hline$>5$ years & 118 & 14.2 & 0.25 & $0.77(0.6 \mathrm{I}-.97)$ \\
Total & 829 & 100 & & \\
\hline
\end{tabular}

isolates were penicillin susceptible, $49.4 \%$ demonstrated intermediate resistance and $14.3 \%$ demonstrated a high level of resistance.

Forty-one percent of the resistant isolates were represented in the heptavalent-conjugate vaccine and the 11 -valent conjugate vaccine, and $53.9 \%$ in the 13 -valent conjugate vaccine.

Stratified Antibiotic Resistance by Age: Susceptibility stratified by serotype and age is shown table III. Although the $<2$ years age group has a higher risk $(75 \%)$ of having resistant serotypes, they are included in the 7 -valent pneumococcal vaccine $(64.7 \%)$.

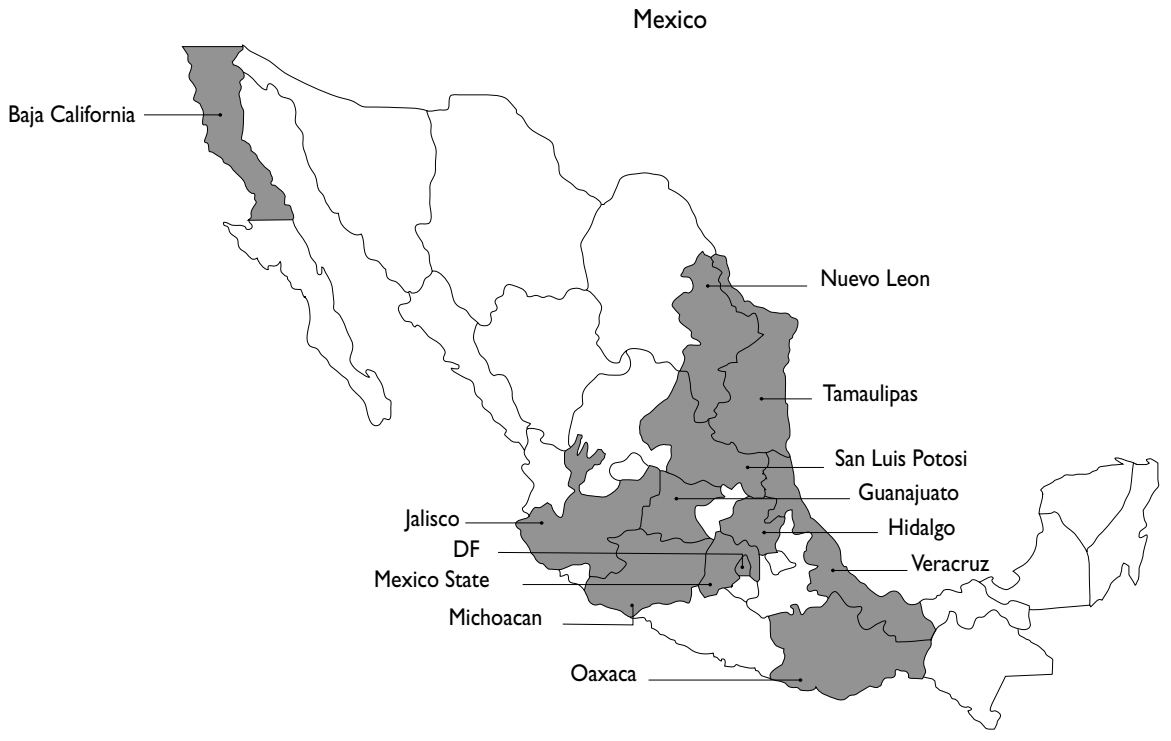

Figure I. Distribution of the day-care centers in 12 states of Mexico 
Table II

Distribution AND SUSCEPTIBILITY OF S.PNEUMONIAE ISOLATES FROM CHILDREN ATTENDING day-Care centers in MeXico

\begin{tabular}{|c|c|c|c|c|c|}
\hline \multirow[t]{2}{*}{ Serotype } & \multirow[t]{2}{*}{ Total No. of isolates } & \multirow[t]{2}{*}{ \% Isolates } & \multicolumn{3}{|c|}{ Penicillin susceptibility } \\
\hline & & & Susceptible & Intermediate & Resistant \\
\hline 3 & 2 & 0.24 & 0 & 2 & 0 \\
\hline 4 & 2 & 0.24 & 0 & 2 & 0 \\
\hline $6 \mathrm{~A}$ & 124 & 14.96 & $49(39.5)$ & $67(54)$ & $8(6.5)$ \\
\hline $6 \mathrm{~B}$ & 129 & 15.56 & $23(17.8)$ & $93(72.1)$ & $13(10.1)$ \\
\hline $7 \mathrm{C}$ & 1 & 0.12 & $\mathrm{I}$ & 0 & 0 \\
\hline $9 \mathrm{~A}$ & 6 & 0.72 & $3(50)$ & $2(33.3)$ & I (16.7) \\
\hline $9 \mathrm{~V}$ & 8 & 0.97 & I (I2.5) & $4(50)$ & $3(37.5)$ \\
\hline $10 \mathrm{~A}$ & 3 & 0.36 & 3 & 0 & 0 \\
\hline IIA & 34 & 4.10 & $29(85.3)$ & $5(14.7)$ & 0 \\
\hline 13 & 31 & 3.74 & $17(54.8)$ & $10(32.2)$ & $4(13)$ \\
\hline 14 & 33 & 3.98 & $8(24.2)$ & $21(63.6)$ & $4(12.2)$ \\
\hline $15 \mathrm{~A}$ & 3 & 0.36 & 0 & $2(66.7)$ & I (33.3) \\
\hline $16 \mathrm{~F}$ & 1 & 0.12 & 0 & 1 & 0 \\
\hline $17 \mathrm{~F}$ & 1 & 0.12 & 1 & 0 & 0 \\
\hline $18 \mathrm{~A}$ & 2 & 0.24 & 2 & 0 & 0 \\
\hline $18 \mathrm{~B}$ & 1 & 0.12 & 1 & 0 & 0 \\
\hline $18 \mathrm{C}$ & 14 & 1.69 & II (78.6) & $3(21.4)$ & 0 \\
\hline $18 \mathrm{~F}$ & I & 0.12 & $\mathrm{I}$ & 0 & 0 \\
\hline $19 \mathrm{~A}$ & 50 & 6.03 & $21(42)$ & $28(56)$ & $I(2)$ \\
\hline $19 \mathrm{C}$ & 1 & 0.12 & 0 & 1 & 0 \\
\hline $19 \mathrm{~F}$ & 191 & 23.04 & $54(28.3)$ & $90(47.1)$ & $47(24.6)$ \\
\hline $22 \mathrm{~F}$ & 20 & 2.41 & $18(90)$ & $2(10)$ & 0 \\
\hline $23 \mathrm{~A}$ & 9 & 1.09 & $4(44.4)$ & $5(55.6)$ & 0 \\
\hline $23 B$ & 3 & 0.36 & I (33.3) & $2(66.7)$ & 0 \\
\hline $23 \mathrm{~F}$ & 93 & 11.22 & $32(34.4)$ & $33(35.4)$ & $28(30.2)$ \\
\hline $28 \mathrm{~A}$ & 6 & 0.72 & $3(50)$ & $3(50)$ & 0 \\
\hline 29 & 6 & 0.72 & 0 & $5(83.3)$ & I (16.7) \\
\hline 34 & 13 & 1.57 & $12(92.3)$ & I (7.7) & 0 \\
\hline $35 \mathrm{~A}$ & 3 & 0.36 & I (33.3) & $2(66.7)$ & 0 \\
\hline $35 B$ & 32 & 3.86 & $2(6.2)$ & $23(71.9)$ & $7(21.9)$ \\
\hline $35 \mathrm{~F}$ & 2 & 0.24 & I (50) & I (50) & 0 \\
\hline 37 & 3 & 0.36 & $2(66.7)$ & I (33.3) & 0 \\
\hline 38 & 1 & 0.12 & 0 & 1 & 0 \\
\hline Total & 829 & 100.00 & $301(36.3)$ & $410(49.4)$ & $118(14.3)$ \\
\hline
\end{tabular}

\section{Conclusions}

This study was conducted in different day-care centers in several cities in Mexico, to ascertain the prevalence of $S$. pneumoniae in children under the age of five. In this study, $29.9 \%$ of Mexican children less than five years of age at- tending day-care centers were pneumococcal carriers, an intermediate figure in relation to other studies where the reported prevalence ranges from 3.6 to nearly $80 \% .{ }^{18-24}$ The variations in prevalence rates between studies may be due to differences in patient populations, sample collection, handling and laboratory techniques. 
Table III

Distribution OF SEROTYPeS REPRESENTED IN 7-VALENT CONJUGATEd VACCINE AND RESISTANT SEROTYPES OF STREPTOCOCCUS PNEUMONIAE BY AGE-GROUPS ISOLATED FROM CARRIER CHILDREN ATTENDING DAY-CARE CENTERS

in MeXico

\begin{tabular}{|c|c|c|c|c|}
\hline \multirow[b]{2}{*}{ Carriers } & \multicolumn{4}{|c|}{ Groups of age (\% total/group of age) } \\
\hline & \multicolumn{2}{|c|}{$\begin{array}{l}\text { Groups of age }(9 \\
2-5 y e a r s\end{array}$} & $>$ yyears & Total \\
\hline Total/age group & \multicolumn{2}{|c|}{1603} & 463 & 2777 \\
\hline Total carriers/age group* & $224(31.5)$ & $487(30.4)$ & $118(25.5)$ & $829(29.9)$ \\
\hline Serotypes represented in 7PCV carriers $^{\ddagger}$ & $145(64.7)$ & $260(53.4)$ & $65(55.1)$ & $470(56.7)$ \\
\hline Resistant serotypes carriers (\%) $)^{\ddagger}$ & $169(75.4)$ & $305(62.6)$ & $54(45.7)$ & $528(63.7)$ \\
\hline \multicolumn{5}{|c|}{ * Numbers in parenthesis are proportions over each total/age group } \\
\hline \multicolumn{5}{|c|}{ \# Numbers in parenthesis are proportions over each carriers total/age group } \\
\hline \multicolumn{2}{|l|}{ Carriers $<2$ years vs. carriers 2 to 5 years } & \multicolumn{2}{|l|}{$p=0.589$} & \\
\hline \multicolumn{2}{|l|}{ Carriers $<2$ years vs. carriers $>5$ years } & \multicolumn{2}{|l|}{$p=0.027$} & \\
\hline \multicolumn{2}{|l|}{ Carriers 2 to 5 years vs. carriers $>5$ years } & \multicolumn{2}{|l|}{$p=0.041$} & \\
\hline \multicolumn{2}{|c|}{ Serotypes represented in $7 P C V$ carriers $<2$ vs. 2 to 5 years } & \multicolumn{2}{|l|}{$p=0.005$} & \\
\hline \multicolumn{2}{|c|}{ Serotypes represented in 7PCV carriers $<2$ vs. serotypes represented in $7 P C V>5$ years } & \multicolumn{2}{|l|}{$p=0.081$} & \\
\hline \multicolumn{2}{|c|}{ Serotypes represented in $7 P C V$ carriers 2 to 5 vs. serotypes represented in $7 P C V>5$ years } & \multicolumn{2}{|l|}{$p=0.740$} & \\
\hline \multicolumn{2}{|c|}{ Serotypes represented $<2$ years vs. carrier resistant serotypes 2 to 5 years } & \multicolumn{2}{|l|}{$p=0.001$} & \\
\hline \multicolumn{2}{|c|}{$\begin{array}{l}\text { Serotypes represented }<2 \text { years vs. carriers resistant serotypes }>5 \text { years } \\
\text { Serotypes represented } 2 \text { to } 5 \text { years vs. carriers resistant serotypes }>5 \text { years }\end{array}$} & \multicolumn{2}{|l|}{$\begin{array}{l}p=<0.001 \\
p=0.002\end{array}$} & \\
\hline
\end{tabular}

The less than six months of age group had a 1.5-fold risk of nasopharyngeal carriage than other age groups.

The analysis shows that children less than two years old $(75 \%)$ had an increased risk of colonization with penicillin-resistant strains in contrast with the older age group (five year-olds) $(p=0.002$ ).

Some previous papers ${ }^{1-3}$ have shown that the less than two years of age group is associated with a higher percentage of nasopharyngeal carriage. These findings could be due to the close contact among children in that age group and, possibly, to the poor immunological response to this bacteria in children under two years of age. . $^{3-4}$

In this study, some geographical differences were observed in the serotype distribution. However, the overall distribution of the carrier status is similar to that in the U.S. ${ }^{21}$ and some European countries; ${ }^{20}$ while there is a significant difference when compared with Asian and African countries. ${ }^{19}, 22-26$ The most frequent serotypes found were: $19 \mathrm{~F}, 6 \mathrm{~B}, 6 \mathrm{~A}, 23 \mathrm{~F}, 19 \mathrm{~A}, 11 \mathrm{~A}$ and $15 B$. These results are consistent with reports from other countries such as the U.S., where the most frequently reported serotypes in those with carrier status have been: $6 \mathrm{~B}, 14,19$ and 23F, and some European countries such as the Netherlands ${ }^{27}$ and Finland, ${ }^{28}$ where predominantly reported serotypes are: $19 \mathrm{~F}, 6 \mathrm{~B}, 6 \mathrm{~A}, 9 \mathrm{~V}$ and $23 \mathrm{~F}$.
Fifty-six percent of the serotypes isolated in the study herein are found in the heptavalent pneumococcal conjugate vaccine. The experimental 11-valent pneumococcal vaccine shows no additional benefit in serotype coverage in this study, but the 13-valent pneumococcal vaccine coverage rate increased to $77 \%$. The coverage is due to the high rate of isolation of serotypes $6 \mathrm{~A}$ and $9 \mathrm{~A}$.

S.pneumoniae susceptibility to penicillin determined in the isolates in the study herein demonstrates a high rate of resistance of $63.7 \%$, with $14 \%$ being high-level resistance. These results suggest the need to continue monitoring resistance rates and, possibly, to change the strategy for treating pneumococcal infections in Mexico. This study's analysis found that children under two years of age are at a greater risk $(78 \%)$ of being colonized by serotypes reported to cause invasive disease as well as to those exhibiting resistance to penicillin, as reported by other authors. ${ }^{29-34}$ While this study did not assess other risk factors related to penicillin resistance, previous observations by the authors ${ }^{10}$ and by others ${ }^{35,36}$ indicate that increased carriage of penicillin-resistant $S$. pneumoniae isolates may be directly related to previous use of beta-lactam antibiotics; although others have not found this association. ${ }^{37}$ The findings in this study regarding penicillin resistance are significant since they 
may have implications for the empirical treatment of pneumococcal infections.

The availability of the heptavalent pneumococcal conjugate vaccine (PCV-7) has demonstrated an important impact on the reduction in invasive pneumococcal disease (IPD) in those vaccinated as well as a significant decrease in IPD in older children and adults. ${ }^{38-42}$ Vaccination has also resulted in diminutions in antibiotics resistance. ${ }^{43}$ With routine utilization of PCV-7 it may be possible to see these benefits in Mexico.

The authors recognize that this study has several limitations. It was performed during autumn and winter; thus, it was not possible to assess the seasonal variation in the colonization rate. Also, the study was conducted in different geographical areas in Mexico, however, not all the existing day-care centers were included and, therefore, the results do not reflect the actual colonization rates throughout Mexico.

\section{Acknowledgments}

We would like to acknowledge all DDC Staff and children for their help.

Distrito Federal: Dra. Leonor Macías, Lic. María Susana Castellanos Gordillo, Dr. Ernesto Lugo Llamosas, Guadalajara: Dra. Martha Marcela Espinoza Oliva, Nuevo León, Monterrey: Dr. Valdemar Abrego y Dra. Alma Rosa Marroquín, León: Dr. Rafael Hernández Magaña, Oaxaca: Dr. Aarón Pérez, Pachuca: Dr. Luciano Mendiola, Tampico: Lic. Celia Matzui Gallardo, Cd. Madero: Dr. Carlos Mendoza, Toluca: Lic. Ma de Lourdes Azpiri Álvarez, San Luis Potosí: Lic. Ada Cristina Rojo Aldana, Xalapa: Lic. Alma Rosa, Zamora: Dr. Jacinto Abarca Ríos, Tecate: Dra. Ana María Cevallos, Ensenada: Dra. Jorge Field, Tijuana: Dr. Enrique Chacón.

Conflicts of interest: none declared.

\section{References}

I. Faden H, Stniacvich J, Brossky L, Bernstein J, Ogra PL. Changes in nasopharyngeal flora during otitis media of childhood. Pediatr Infect Dis J 1990; 9(9):623-626.

2. Faden H, Dufty L,Wasielewski R,Wolf J, Krystofik D, Tung Y. Relationship between nasopharyngeal colonization and development of otitis media in children.J Infect Dis 1997; I75(6): I440-1445.

3. Gray BM, Converse GM, Dillon H. Epidemiologic studies of Streptococcus pneumoniae in infants: acquisition, carriage and infection-during the first 24 months of life.J Infect Dis 1980; 142(6):923-933.

4. Lakshman R, Murdoch C, Race G, Burkinshaw R, Shaw L, Finn A.

Pneumococcal nasopharyngeal carriage in children following heptavalent pneumococcal conjugate vaccination in infancy. Arch Dis Child 2003;88(3):2II-2I4.
5. Matense OC, Paula A, Moraes AB, Moreira TA, Guerra ML, Brandileone MC. Prevalence of serotypes and antimicrobial resistance of invasive strains of Streptococcus penumoniae.J Pediatric (Rio J). 2003;79(6):537-542. 6. Block SL, Harrison CJ, Hedrick JA, Tyler RD, Smith RA, Keegan E, Chartrand SA. Penicillin-resistant Streptococcus pneumoniae in acute otitis media: risk factors, susceptibility patterns and antimicrobial management. Pediatr Infect Dis J 1995; I4(9):75।-759.

7.Appelbaum PC,Antimicrobial resistance in Streptococcus pneumoniae: an overview. Clin Infect Dis 1992;15:77-83.

8. Reichler MR,Allphin AA, Breiman RF, Schreiber JR,Arnold JE, McDouglas LK, et al. The spread of multiply resistant Streptococcus pneumoniae at a day care center in Ohio. J Infect Dis 1992;166(6): I346-1353.

9. De Lencastre H, Kristinsson KG, Brito-Avo A, Sanches IS, Sa-Leao R, Saldanha J. et al. Carriage of respiratory tract pathogens colonization in healthy children attending day-care center in Lisbon, Portugal. Microb Drug Resist 1999; 5(I):19-29.

10. Gomez D, Calderon E, Rodriguez R, Espinosa de los Monteros LE,Viña L, Jimenez LV. Carriage of antibiotic-resistant pneumococci in a cohort of a day-care center. Salud Publica de Mexico 2002;44:26-32.

I I. Takala AK, Jero J, Kela E, Ronnberg PR, Koskenniemi E, Eskola J. Risk factors for primary invasive pneumococcal disease among children in Finland. JAMA 1995;273(II):859-864.

12. Black S, Shinefield H, Fireman B, Lewis E, Ray P, Hansen LR, et al. Efficacy of heptavalent pneumococcal vaccine in children. Pediatr Infect Dis J 2000;19(3): 187-195.

I3. Whitney CG, Farley MM, Hadler J, Harison LH, Bebbett NM, Lynfield $R$, et al. Decline in invasive pneumococcal disease after the introduction of protein- polysaccharide conjugate vaccine. N Engl J Med 2003;348(I8): : 1737- 1745.

14. O'Brien KL, Nohynek $\mathrm{H}$ and the WHO pneumococcal vaccine trials carriage working group. Report from WHO working group: standard method for detecting upper respiratory carriage of S.pneumoniae. Pediatr Infect Dis J 2003;22:I - II.

15. National Committee for Clinical Laboratory Standards 2002. Performance standards for antimicrobial susceptibility testing; sixth informational supplement. NCCLS document Vol 22 .MI00-SI2. 16. Pediatric vaccine. Streptotrix. www. glaxosmithkline.com 17. Fletcher MA, Laufer DS, Mcintosh EDG, Cimino C, Malinoski FJ. Controlling invasive pneumococcal disease; is vaccination of all risk groups sufficient? Int J Clin Pract 2006. 60;40:450-456.

18.Appelbaum PC, Gladkova C, Hryniewicz W, Kojouharov B, Kotulova D, Mihaucu F, et al. Carriage of antibiotic resistant Sreptococcus pneumoniae by children in Eastern and Central Europe. Clin Infect Dis 1996;23(4): 712-717. 19. Sung RY, Ling JM, Fung SM, Oppenheimer SJ, Crook DW, Lau JT, et al. Carriage of Haemophilus influenzae and Streptococcus pneumoniae in healthy Chinese and Vietnamese children in Hong Kong.Acta Paediatr 1995; 84; 1262-1267.

20. Marchisio P, Esposito S, Schito GC, Marchese A, Cavagna R, Principi $\mathrm{N}$, et al. Nasopharyngeal carriage of Streptococcus pneumoniae in healthy children: Implications for the use of heptavalent pneumococcal conjugate vaccine. Emerg Infect Dis 2002; 8(I5):479-484.

21. Ghaffor F, Friedland IR, McCracken GH Jr. Dynamics of nasopharyngeal colonization by Streptococcus pneumoniae. Pediatr Infect Dis J 1999; 18: 638-646.

22. Yagupsky P, Porat N, Fraser D, Prajgrod F, Merires M, Mc Gee L, Klugman KP et al.Acquisition, carriage, and transmission of pneumococcal with decreased antibiotic susceptibility in young children attending a daycare facility in Southern Israel.J Infect Dis 1998; 177(4): 1003-1012. 23. Chiu SS, Ho LP, Chow K, Yuen YK, Lau YL, et al. Nasopharyngeal carriage of antimicrobial-resistant Streptococcus pneumoniae among young children attending 79 kindergartens and Day-care center in Hong Kong. Antimicrob Agents Chemother. 200 I;45(I0): 2765-2770. 
24. Bogaert D, De Groot, Hermans PW. Streptococcus pneumoniae colonization: the key to penumococcal disease. Lancet Infect Dis 2004;4(3): I44-I54.

25. Black S, Shinefield H, Baxter R, Austrian R, Brackeu L, Hansen J et al. Postlicensure surveillance for Pneumococcal Invasive Disease after use of Heptavalent Pneumococcal Conjugate Vaccine in Northern California Kaiser Permanente. Pediatric Infect Dis J. 2004;23(6):485-497.

26. HausdorffWP, Bryant J, Paradiso PR, Siber GR. Which pneumococcal serogroups cause the most invasive disease: implications for conjugate vaccine formulation and use; Part I. Clin Infect Dis 2000;30:100-I2I. 27.Veenhoven RH, Bogaert D, Schilder AG, Rijkers GT, Uiterwaal CS, Kiezebrink $\mathrm{HH}$, et al. Nasopharyngeal Pneumococcal carriage after combined Pneumococcal conjugate and polysaccharide vaccination in children with a history of Recurrent Acute Otitis Media. Clin Infect Dis 2004;39(7):911-919.

28. Eskola J, Kilpi T, Palmu A, Jokinene J, Haapakoski J, Herva E, et al. Efficacy of a Pneumococcal conjugate Vaccine against acute otitis media. N Engl J Med 200I;344(6):403-409.

29. Whitney CG, Farley MM, Hadler J, Harrison LH, Lexauc C, Reingold A, et al. Increasing prevalence of multidrug resistant Streptococcus pneumoniae in the United States. N Engl J Med 2000; 343(26):1917-1924.

30. Dagan R, Melamed R, Muallen M, Piglansky L, Yagupsky P. Nasopharyngeal colonization in Southern Israel with antibiotic-resistant pneumococci during the first 2 years of life: relation to serotypes likely to be included in pneumococcal conjugate vaccines.J Infect Dis 1996; 174(6);।352-5.

31. Block SL, Hedrick J, Harrisan CJ, Tyler R, Smith A, Findlay R, et al. Pneumococcal serotypes from acute otitis media in rural Kentucky. Pediatr Infect Dis J. 2002;2I (9):859-865.

32. Kaplan SL, Mason EO Jr,Wald ER, Tan TO, Schutze GE, Bradley JS, et al. Six years multicenter survillance of invasive pneumococcal infections in cchildren. Pediatr Infec Dis J. 2002;2I(2): I4I-I47.

33. Hortal M, Lovgren M, De la Hoz F,Agudelo Cl, Brandileone MC, Camou T, et al.Vigia Study Groups. Antibiotic resistance in Streptococcus pneumoniae in six Latin America Countries: 1993-1955 Surveillance. Microb Drug Resist 200I; 7(4):391-40I.

34. Henderson FW, Gillang PH,Wait K, Goff DA. Nasopharyngeal carriage of antibiotic-resistant pneumococci by children in group day-care. J Infect Dis 1988;157(2):256-263.

35. Norris CF, Mahannah SR, Smith-Whittey K, Ohene-Frempong K, McGowan GL. Pneumococal colonization in children with sickle cell disease.J Pediatr 1996; 129(6): 821-827.

36. Kaleida PH, Nativio GP, Chao H, Cowden SN. Prevalence of bacterial respiratory pathogens in the nasopharynx in breast- left versus formulafed infants.J Clin Microbiol 1993;31(10):2674-2676.

37. Riley ID, Lehmann D,Alpers MP, Marshall TF, Gratten H, Simth D, et al. Pneumococcal vaccine prevents death from acute lower-respiratory-tract infections in Papua New Guinean children. Lancet 1986; 2(85I2):877-88I. 38. Whitney CG, Pickering LK. The potential of pneumococcal conjugate vaccines for children. Pediatr Infect Dis J 2002;2I(10):961-970.

39. Melegaro A, Edmunds W], Pebody R, Miller E, George R. The current burden of penumococcal disease in England and Wales.J Infection. 2006; 52(I):37-48.

40. Hennessy TW, Singleton RJ, Bulkow LR, Bruden DL, Hurburt DA, Parks D, et al. Impact of heptavalent resistance and colonization in Alaska Natives: progress towards elimination of health disparity.Vaccine, 2005;23(49-49): 5464-5473.

41.Tropical Public Health Unit CDC Newsletter. Invasive Penumococcal Disease in Indigenous Children in North Queensland, 1999-2004. Tropical Public Health Unit, Communicable Disease Control, 2005;5 I:5-7.

42. Metlay J P, Fishman NO, Joffe M, Edelstein PH. Impact of Pediatric vaccination with pneumococcal conjugate vaccine on the risk of bacteremic penumococcal pneumonia in adults. Vaccine, 2006; 24(4):468-475. 43. Moore MR, Hyde TB, Hennessy TW, Parks DJ, Reasonover PA, Harker-Jones M, et al . Impact of a Conjugate Vaccine on community-wide carriage of nonsusceptible Streptococcus pneumoniae in Alaska.J Infecti Dis 2004; I90(I):203I-2038. 